\title{
Correction to: Open Science and the Science-Society Relationship
}

\author{
Martin Lakomý ${ }^{1}$ - Renata Hlavová ${ }^{2} \cdot$ Hana Machackova ${ }^{2}$
}

Published online: 13 September 2019

(C) The Author(s) 2019

\section{Correction to: Soc (2019) 56:246-255}

https://doi.org/10.1007/s12115-019-00361-w

The article Open Science and the Science-Society Relationship, written by Martin Lakomý, Renata Hlavová, Hana Machackova, was originally published electronically on the publisher's internet portal (currently SpringerLink) on June 24, 2019 without open access. With the author(s)' decision to opt for Open Choice the copyright of the article changed on September 16, 2019 to (C) The Author(s) 2019 and the article is forthwith distributed under the terms of the Creative Commons Attribution 4.0 International License (http://creativecommons.org/licenses/by/4.0/), which permits use, duplication, adaptation, distribution and reproduction in any medium or format, as long as you give appropriate credit to the original author(s) and the source, provide a link to the Creative Commons license and indicate if changes were made.

The original article has been corrected.

Open Access This article is distributed under the terms of the Creative Commons Attribution 4.0 International License (http:// creativecommons.org/licenses/by/4.0/), which permits unrestricted use, distribution, and reproduction in any medium, provided you give appropriate credit to the original author(s) and the source, provide a link to the Creative Commons license, and indicate if changes were made.

Publisher's Note Springer Nature remains neutral with regard to jurisdictional claims in published maps and institutional affiliations.

The online version of the original article can be found at https://doi.org/ 10.1007/s12115-019-00361-w

Martin Lakomý

lakomy@ fss.muni.cz

1 Office for Population Studies/Department of Sociology, Faculty of Social Studies, Masaryk University, Brno, Czechia

2 Institute for Research on Children, Youth and Families, Faculty of Social Studies, Masaryk University, Brno, Czechia 